\title{
Arte, muitos são os sentidos ...*
}

Antonio Pithon Cyrino ${ }^{1}$

O que podemos contra todas as forças que ao nos atravessarem nos querem fracos, tristes, servos e tolos?

Criar!: a resposta alegre!

(Deleuze, 1992)

O Centro de Saúde Escola (CSE) da Faculdade de Medicina de Botucatu - Unesp abriu em novembro de 2.000 sua Mostra Permanente de Arte.

Luz, cores, formas, poesia... agora ocupam o espaço institucional, enquanto fonte propulsora da ação criativa e do jogo lúdico daqueles que contemplam, admiram, pensam, experimentam.

A Mostra, enquanto exposição pública dos trabalhos, é parte de um projeto que tem como preocupação central a comunicação que o serviço estabelece com seus usuários e a sociedade. Buscou ampliar esta comunicação estreitando as interfaces entre Arte e Saúde.

o Projeto Mostra Permanente de Arte viabilizou-se com a contribuição e criatividade de quatro artistas plásticos de Botucatu² que durante dois anos trabalharam em sua produção. Este projeto permitiu, ainda, que estes artistas realizassem oficinas de arte com dois grupos de usuários da Saúde Mental do CSE, o Ateliê Planeta Arte e o Grupo Reviver.
Esta vivência certamente permitiu a esses grupos a expressão de outros dizeres, bem como tecer muitos fios na rede social que os integra e os fortalece como cidadãos.

Com a Mostra Permanente de Arte, o CSE reafirmou sua preocupação crescente em discutir e implementar novas práticas de comunicação, construindo novos espaços de cidadania e trazendo a Arte em seus múltiplos sentidos para mobilizar nos usuários a expressão e a alegria de ver e dizer. Pois, como observa Laymert Garcia dos Santos (1989, p.13):

Dizer é momento de produção de afirmação. Momento de expulsão, de esconjuro, de exorcismo das forças da morte que se apropriam da energia vital. Dizer é momento de luta feroz e surda, de sopro de vida. Dizer já é um início de vitória - mas não se diz o começa da luta, este é indizível.

\footnotetext{
* Coordenaram a Mostra Permanente de Arte: Antonio Pithon Cyrino, Elisete Alvarenga, Maria Eunice Carreiro Lima e Martha Helena Dias Araújo de Andrade.

${ }_{1}^{1}$ Professor do Departamento de Saúde Pública, Faculdade de Medicina de Botucatu, Universidade Estadual Paulista/Unesp. Diretor do Centro de Saúde Escola. <acyrino@fmb.unesp.br>

2 Elisete Alvarenga, Luciana Beth, Mônica Stein e Olavo Pupo.
} 


\section{Referências bibliográficas}

DELEUZE, G. Conversações. Rio de Janeiro: Ed.34, 1992.

SANTOS, L.G. Tempo de ensaio. São Paulo: Companhia das Letras, 1989.

PALAVRAS-CHAVE: Arte; Comunicação; serviços de Saúde. KEY WORDS: Art; Communication; Healthcare services.

PALABRAS-CLAVE: Arte; Comunicación; servicios de salud

Recebido para publicação em: 14/01/01. Aprovado para publicação em: 24/01/01.
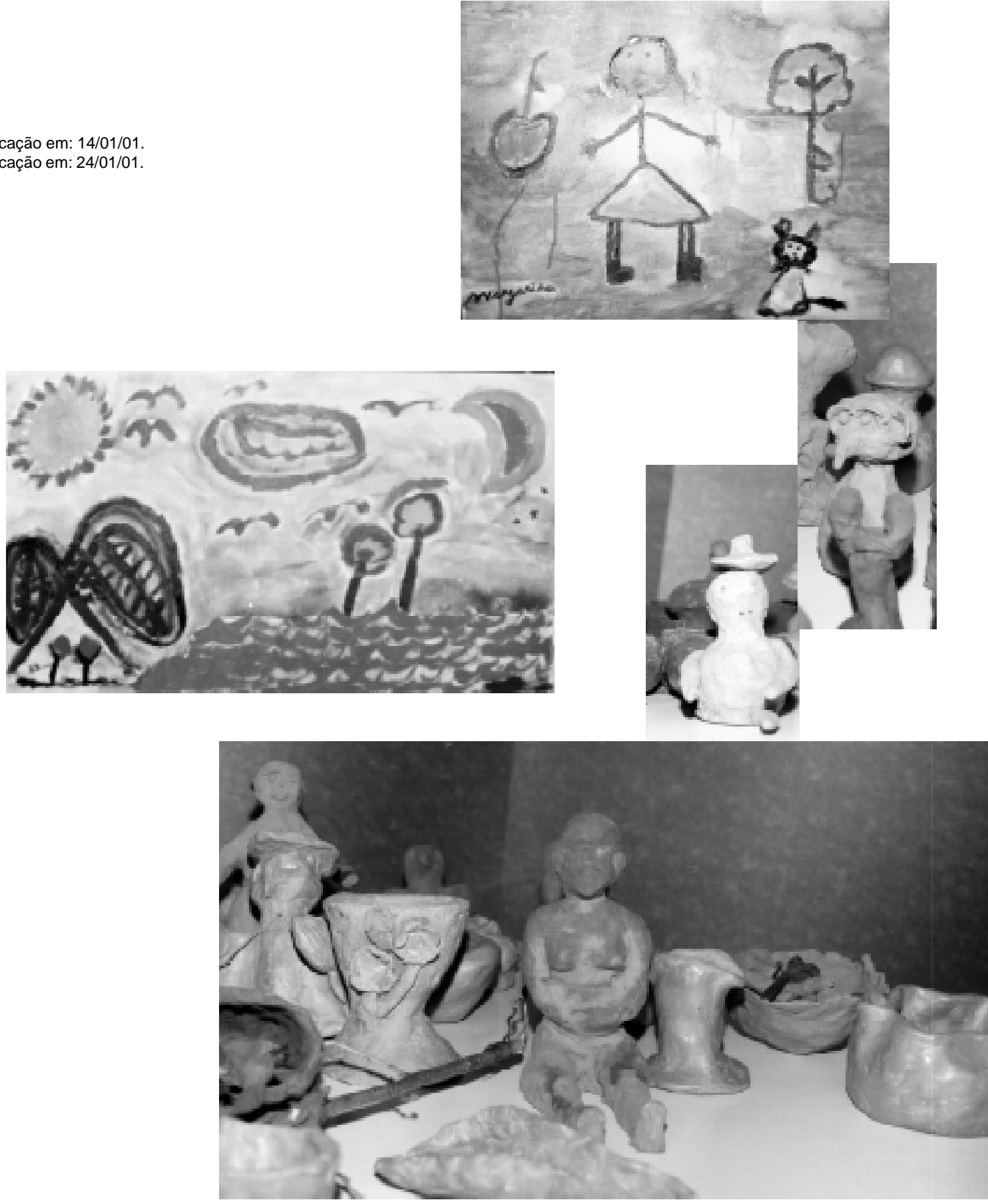

Trabalhos dos grupos Planeta Arte e Reviver, 2000, CSE, Botucatu

158 Interface - Comunic, Saúde, Educ 8 